\title{
Podiform chromitites from the Variscan ophiolite serpentinites of Lower Silesia (SW Poland) - petrologic and tectonic setting implications
}

\author{
Piotr Marian WOJTULEK ${ }^{1,{ }^{*}}$, Jacek PUZIEWICZ ${ }^{1}$, Theodoros NTAFLOS ${ }^{2}$ and Michał BUKAŁA ${ }^{1}$ \\ 1 University of Wrocław, Institute of Geological Sciences, pl. M. Borna 9, 50-204 Wrocław, Poland \\ 2 University of Vienna, Department of Lithospheric Research, Althanstrasse 14, 1090 Vienna, Austria
}

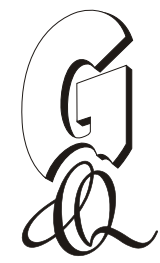

\begin{abstract}
Wojtulek, P.M., Puziewicz, J., Ntaflos, T., Bukała, M., 2016. Podiform chromitites from the Variscan ophiolite serpentinites of Lower Silesia (SW Poland) - petrologic and tectonic setting implications. Geological Quarterly, 60 (1): 56-66, doi: $10.7306 / \mathrm{gq} .1238$

The Gogołów-Jordanów Serpentinite Massif (GJSM) and the Braszowice-Brzeźnica Massif (BBM) are the largest serpentinite outcrops in the Fore-Sudetic Block (NE part of the Bohemian Massif, Central Europe). The GJSM is a peridotitic member of the Variscan Ślęża Ophiolite (SW Poland). Podiform bodies (veins and pockets) of chromitite are found on the Czernica Hill (GJSM) and on the Grochowiec Hill (BBM) within strongly serpentinised harzburgites which occur several hundred metres below Palaeo-Moho. Chromitites consist of rounded chromite grains up to $3 \mathrm{~cm}$ across, and of chlorite filling the interstices. The veins are embedded in serpentine-olivine-chlorite aggregates. Relics of Mg-rich olivine ( Fo $_{95-96}$ ) occur in massive chromitite in the BBM. The bulk-rock total PGEs content is very low (42-166 ppm) and the PGE pattern is negatively sloped towards $\mathrm{Pt}$ and $\mathrm{Pd}$ and depleted relative to chondrite. The primary chromite I is aluminous (Cr\# $0.50-0.52, \mathrm{Mg} \#$ $0.60-0.70)$. The highly aluminous and magnesian ( $\mathrm{Cr} \# 0.38, \mathrm{Mg} \# 0.80)$ chromite la occurs locally in the BBM. The secondary chromite II is enriched in $\mathrm{Cr}$ and impoverished in $\mathrm{Al}(\mathrm{Cr} \#$ 0.57-0.69), it replaces chromite I. Both chromite I and II contain small amounts of $\mathrm{Ti}\left(<0.14 \mathrm{wt} . \% \mathrm{TiO}_{2}\right)$. Silicate inclusions in chromite are scarce. The composition and mode of occurrence of both the GJSM and the BBM chromitites are similar, thus they were formed probably under the same conditions. Textures of the chromitites suggest their magmatic origin. Their current geological position indicates their emplacement and crystallisation in the uppermost mantle harzburgites occurring below the Moho Transition Zone. The chromitites and hosting harzburgites were subjected to the greenschist-facies metamorphic overprint. The moderate Cr\# and low PGEs contents suggest that the chromitites originated in the arc setting, thus their host ophiolite is of supra-subduction type.
\end{abstract}

Key words: ophiolite, chromitite, platinum group elements (PGE), supra-subduction setting, Variscan orogeny.

\section{INTRODUCTION}

Chromitites are rocks containing $\geq 90 \%$ of chromite. They are associated worldwide with ophiolites of all ages (González-Jiménez et al., 2014). Interpretation of the origin of chromite occurring in chromitites is difficult because various factors affect its composition, like melt composition, crystallisation conditions and sub-solidus processes (e.g., Python et al., 2008). The relationships between chromite composition and tectonic setting (cf. Rollison and Adetunji, 2013), as well as the mechanism of chromite crystallisation (cf. Borisova et al., 2012, González-Jiménez et al., 2014) are still the matters of discussions.

This paper presents new data (textural observations, chromite PGE composition and sulphide secondary phases composition) on chromitites associated with serpentinites occurring in the Variscan ophiolitic sequences from the NE margin of the

\footnotetext{
* Corresponding author, e-mail: piotr.wojtulek@interia.pl
}

Received: May 28, 2014; accepted: May 4, 2015; first published online: June 30, 2015
Bohemian Massif in Central Europe (Fig. 1). We show that chromitites have well-preserved primary igneous features, which, however, have been overprinted by low-grade metamorphism. Our data suggest that the back-arc is the potential setting in which the chromitites formed.

\section{GEOLOGICAL SETTING}

\section{THE GOGOŁÓW-JORDANÓW SERPENTINITE MASSIF}

The Ślęża Ophiolite from south to north consists of serpentinites and serpentinised rocks rich in pyroxene and amphibole (Gogołów-Jordanów Serpentinite Massif, GJSM), metagabbros, amphibolites and metamorphosed dark radiolarian cherts (Majerowicz, 1979). These rocks (Fig. 1C) are interpreted as mantle peridotites, ultramafic cumulates, gabbros, volcanic member with sheeted dyke complex, pillow lavas and oceanic sediments (Majerowicz, 1979; Floyd et al., 2002). According to Pin et al. (1988), the gabbroic and volcanic members reveal N-MORB affinity (based on a trace element study, e.g. Th, Nb and Yb contents). U-Pb SHRIMP dating of zircons from metagabbroic and metavolcanic rocks yielded the age of the magmatic crystallisation of the Ślęża Ophiolite at 


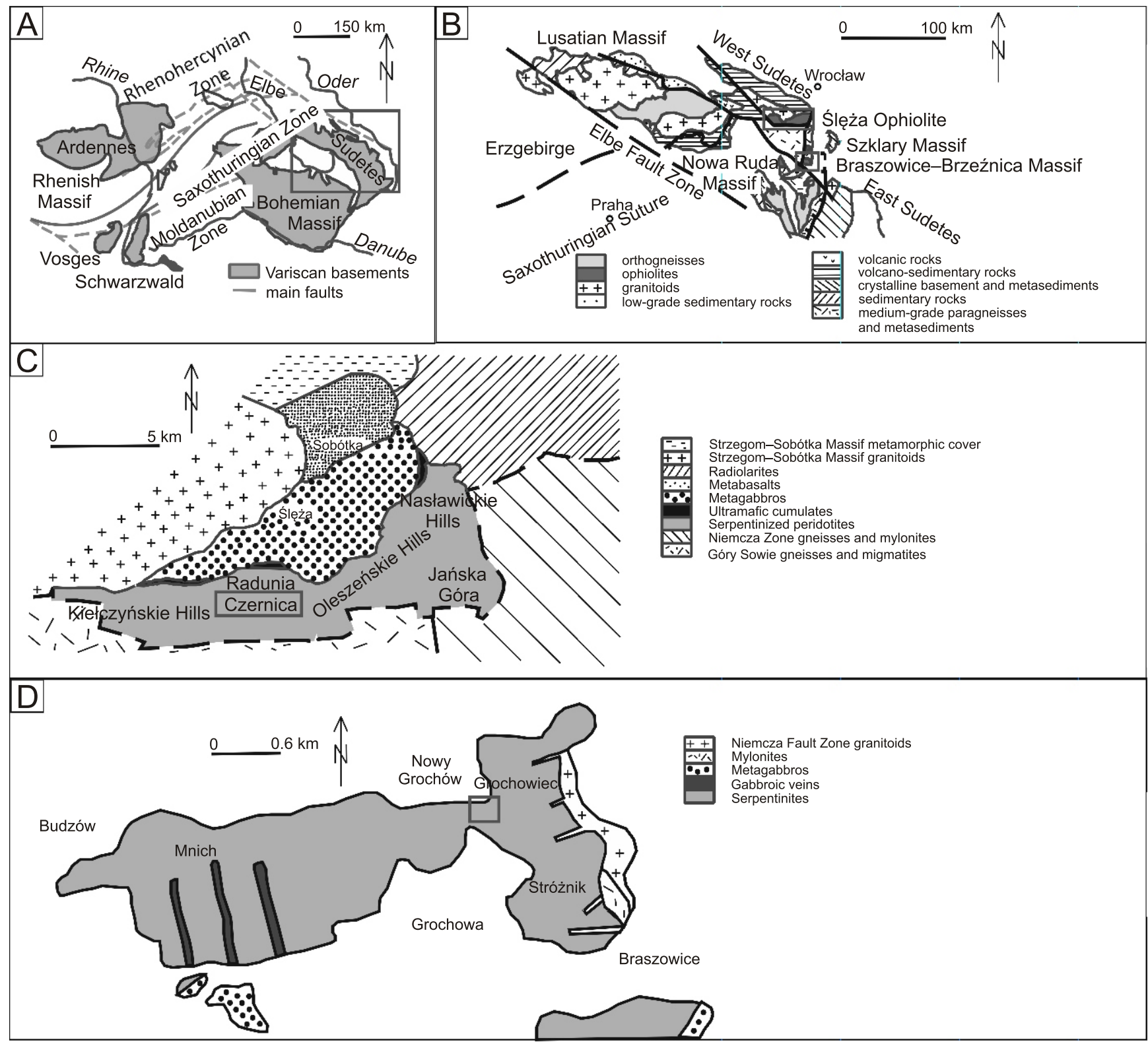

Fig. 1. Geological setting of the Gogołów-Jordanów Serpentinite Massif (GJSM) and the Braszowic-Brzeźnica Massif (BBM)

A - geological sketch-map of the Variscan orogen in Central Europe (modified from Kossmat, 1927); B - geological sketch-map of the northern part of the Bohemian Massif (modified from Aleksandrowski and Mazur, 2002); C - geological sketch-map of the Ślęża Ophiolite (modified from Majerowicz, 1994 in Kryza and Pin, 2010); D - geological sketch-map of the Braszowice-Brzeźnica Massif (modified from Gunia, 1992)

$400 \pm 10 \mathrm{Ma}$ and $403 \pm 6 \mathrm{Ma}$ (Kryza and Pin, 2010). A study of zircon grains from the contact zone between rodingite dyke and serpentinite ("blackwall") using the ${ }^{206} \mathrm{U}-{ }^{238} \mathrm{~Pb}$ method yielded the age of $400+4 /-3 \mathrm{Ma}$, interpreted as the age of serpentinisation (Dubińska et al., 2004) or as the age of crystallization of gabbroic dykes constituting the protolith of the rodingite (Kryza and Pin, 2010). The Nd radiogenic isotopes of six "whole rock" samples of the Ślęża Ophiolite (Pin et al., 1988) yielded model ages ranging between $353 \pm 21 \mathrm{Ma}$ and $351 \pm 16 \mathrm{Ma}$. These dates according to Kryza and Pin (2010), represent the age of metamorphic overprint.

The GJSM consists typically of serpentinised peridotites, whereas unaltered rocks are scarce (Dubińska and Gunia, 1997). Small-sized plagiogranitic and rodingitic bodies occur within the serpentinites in the eastern part of the GJSM (Majerowicz, 1979;
Dubińska and Gunia, 1997). Carbonate rocks consisting of magnesite and dolomite were interpreted as ophicarbonates (Jędrysek and Hałas, 1990). The GJSM serpentinites recorded low- to mid-temperature serpentinisation events under conditions corresponding to greenschist - lower stage amphibolite facies of regional metamorphism (Dubińska and Gunia, 1997).

\section{THE BRASZOWICE-BRZEŹNICA MASSIF}

The Braszowice-Brzeźnica Massif (BBM) is located in the south end of the Niemcza Dislocation Zone and consists of gabbros and serpentinites (Fig. 1D). The ultramafic rocks forming the BBM are (from $E$ to $W$ ) serpentinites with abundant relics of olivine and tremolite, lizardite-chrysotile serpentinites and 
antigorite serpentinites (Gunia, 1992). Serpentinitic-magnesitic-dolomitic breccias, magnesite accumulations, rodingite and pyroxenite veins or irregular bodies occur mostly in the western part of the BBM (Gunia, 1992). Aplite veins occur in the eastern part of the massif, near a small granitic intrusion. The age of the serpentinites is assumed to be analogous to that of the serpentinites and gabbros from the Ślęża Ophiolite (Dziedzic and Dziedzicowa, 2000).

\section{SAMPLING AND ANALYTICAL METHODS}

The data presented in this paper are based on an overview of 50 samples of chromitites and serpentinites collected from three dumps of abandoned mines (two from the Czernica Hill GJSM and one from the Grochowiec Hill - BBM), eight of which have been studied in detail (Appendix $1^{*}$ ). We sampled the dumped rocks since chromitites are not exposed at the surface. Near the Czernica Hill, chromitites were mined from two exploitation levels (350 and $450 \mathrm{~m}$ above sea level) by two (now abandoned) shafts (Spangenberg, 1943). The dumps are located close to them. In the BBM, one abandoned shaft at the level of $275 \mathrm{~m}$ a.s.I. is located in the southwestern slope of the Grochowiec Hill, with the dump in its close vicinity.

The major element composition of minerals has been analysed by electron microprobe (Cameca SX-100 at Department of Lithospheric Research, University of Vienna, Austria) under standard conditions (acceleration voltage $15 \mathrm{kV}$, sample current $15 \mathrm{nA}$, counting times 10 or $20 \mathrm{~s}$, natural silicates and synthetic oxides as standards). PAP correction procedure was applied. Counting times were lengthened to improve detection limits for $\mathrm{Ni}$ and $\mathrm{Ca}$. Usually, five to seven grains were analysed in each thick section. We used $150 \mu \mathrm{m}$ thick sections for electron microprobe. The amounts of $\mathrm{Fe}^{3+}$ and $\mathrm{Fe}^{2+}$ in spinel were calculated by charge balance. All $\mathrm{Fe}$ is assumed to be $\mathrm{Fe}^{2+}$ in silicates.

Bulk-rock chemical compositions (20 samples analysed, including 10 massive chromitites) were determined by inductively coupled plasma mass spectrometry $(200 \mathrm{mg}$ sample, $\mathrm{LiBO}_{2}-\mathrm{LiB}_{4} \mathrm{O}_{7}$ fusion) at ACME Analytical Laboratory in Vancouver, Canada. Minimum detection limits for main oxides were: $\mathrm{SiO}_{2}, \mathrm{Al}_{2} \mathrm{O}_{3}, \mathrm{MgO}, \mathrm{CaO}, \mathrm{Na}_{2} \mathrm{O}, \mathrm{K}_{2} \mathrm{O}, \mathrm{TiO}_{2}, \mathrm{P}_{2} \mathrm{O}_{5}$ and $\mathrm{MnO}$ - 0.01 wt. \%; $\mathrm{Fe}_{2} \mathrm{O}_{3}-0.04$ wt. \%; $\mathrm{Cr}_{2} \mathrm{O}_{3}-0.02$ wt.\%. For the other investigated elements, the minimum detection limits were: V - 8 ppm; Sc, Ba, Be, Sn, Zn-1 ppm; Ga, Sr, W, As, Se - 0.5 ppm; Nd - 0.3 ppm; Co, Th-0.2 ppm; Cs, Hf, Nb, Rb, Ta, $\mathrm{U}, \mathrm{Zr}, \mathrm{Y}, \mathrm{La}, \mathrm{Ce}, \mathrm{Mo}, \mathrm{Pb}, \mathrm{Ni}, \mathrm{Sb}, \mathrm{Cd}, \mathrm{Bi}, \mathrm{Ag}-0.1 \mathrm{ppm} ; \mathrm{Sm}, \mathrm{Gd}$, Dy, Yb-0.05 ppm; Pr, Eu, Ho - 0.02 ppm; Tb, Tm, Lu, Hg $0.01 \mathrm{ppm} ; \mathrm{Au}-0.5 \mathrm{ppb}$.

The composition of platinum group elements (PGEs) in the chromitites ( 9 samples analysed) was determined at ACME Analytical Laboratory in Rustenburg, the Republic of South Africa, by the fire assay analysis using nickel sulphide as the collecting medium. For the platinum group elements (PGE) the minimum detection limit was $1 \mathrm{ppb}$.

\section{OCCURRENCE AND PETROGRAPHY OF CHROMITITES}

THE GOGOŁÓW-JORDANÓW MASSIF

The host rock of chromitites, although strongly serpentinised, can still be recognized as former mantle harzburgite or

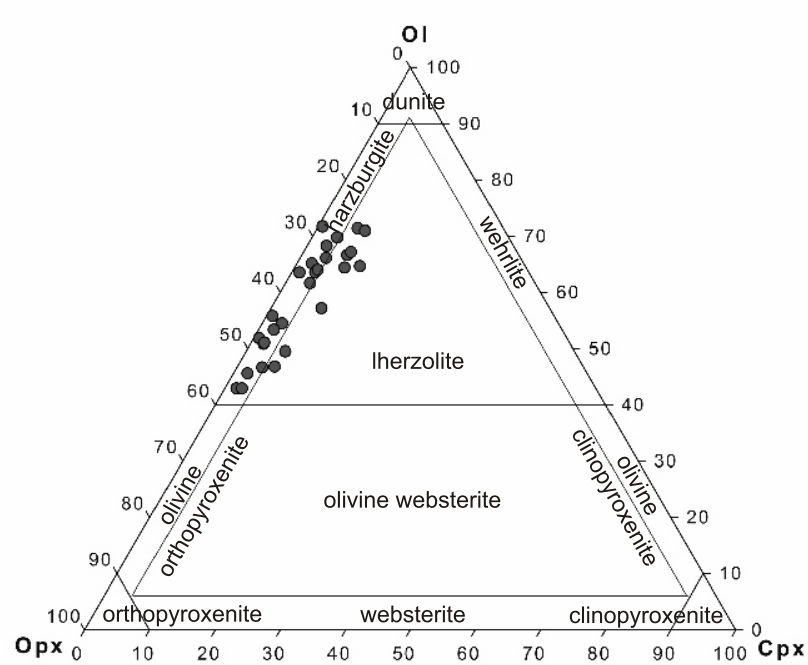

Fig. 2. Normative composition of the GJSM serpentinite protolith (CIPW-norm calculated) on the Streckeisen ultramafic rocks classification diagram (Streckeisen et al., 1974)

dunite. The mesh texture of altered olivine is still preserved, and bastites (former enstatite) are abundant. The interstitial clinopyroxene-olivine-spinel assemblages interpreted to be the relics of melt-percolation phases (Wojtulek et al., 2013) occur in the serpentinites. Normative mineral compositions calculated from the bulk-rock chemistry indicate low content of clinopyroxene in the primary igneous assemblage (typically from 0 to $10 \mathrm{vol} . \%$ ), while the orthopyroxene content is between 28 and $58 \%$ (Fig. 2). This is consistent with former data of Majerowicz (2006).

The chromitites occur as pockets and veins within serpentinites of the Czernica Hill (Fig. 1; 50 49'42" N, $\left.16^{\circ} 42^{\prime} 64^{\prime \prime} \mathrm{E}\right)$. Spangenberg (1943) suggested that the elongation of the chromitite bodies indicates an extension of the chromitite-bearing zone in the NE-SW direction. The mined pockets in the Czernica Hill were 8-12 $\times 4-3 \times 2-4 \mathrm{~m}$ in size (Birecki, 1962) and had the stock morphology with irregular boundaries (Spangenberg, 1943). The chromite-bearing veins were up to $22 \mathrm{~m}$ long and $2 \mathrm{~m}$ thick. Usually, the smaller ore bodies occur close to larger pockets. The ore bodies were surrounded by alteration zones (salbands) which contained less chromian spinel (Spangenberg, 1943). The fabric of the Cr-ore marked by the elongation of chromite aggregates was concordant with the ore-body elongation (Spangenberg, 1943). The chromitites that occur in serpentinites from the Czernica Hill are cut by aplite veins (Birecki, 1962).

The detailed study of chromitites was presented by Delura (2012a). In structural terms, chromitites from the GJSM can be subdivided into (1) massive, (2) laminated, (3) nodular, (4) disseminated, (5) brecciated and (6) veinlets within serpentinite. The mined ore pockets were composed mostly of massive chromitite (Fig. 3A), whereas lower grade, disseminated chromite ore (Fig. 3B, D) occurred subordinately. According to Spangenberg (1943), the chromitite bodies are hosted by dunites. Our study of bulk-rock chemistry (Fig. 2) as well as bulk-rock analyses of Majerowicz (2006) do not reveal the occurrence of dunites, although locally the thin sections show the alteration textures typical for those rocks. The bulk-rock data reveals harzburgitic and lherzolitic CIPW normative composition. 

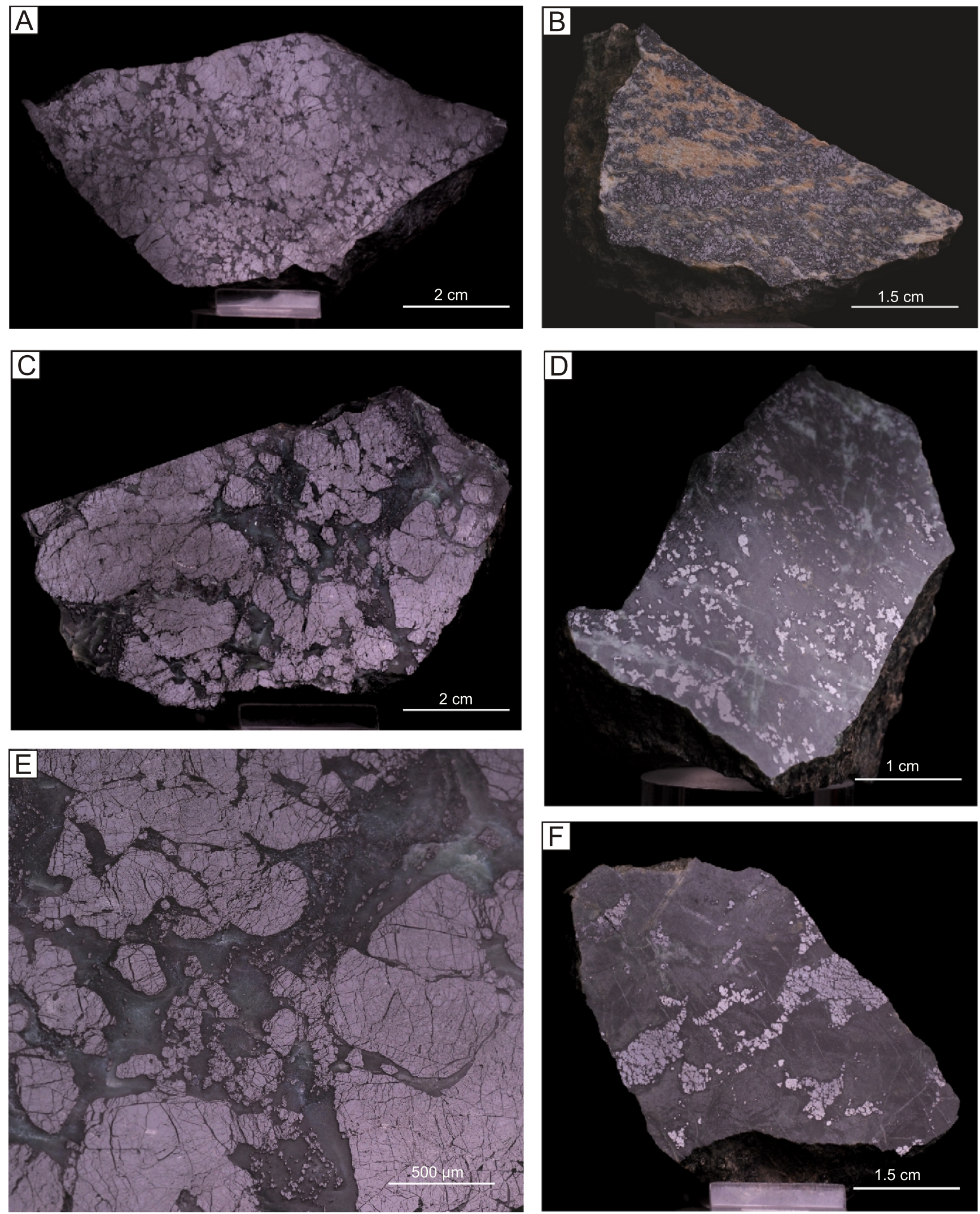

Fig. 3. Macroscopic appearance of the GJSM and BBM chromitites

A - massive ore from the GJSM (sample S6); B - elongated chromite aggregates from the GJSM (sample S4); C - brecciated-nodular ore from the BBM (sample S28); D - disseminated, dispersed ore from the BBM (sample S32); $\mathbf{E}$ - brecciated-nodular ore in higher magnification (sample S28); F - chromite veinlet within serpentinite from the GJSM (sample S3) 

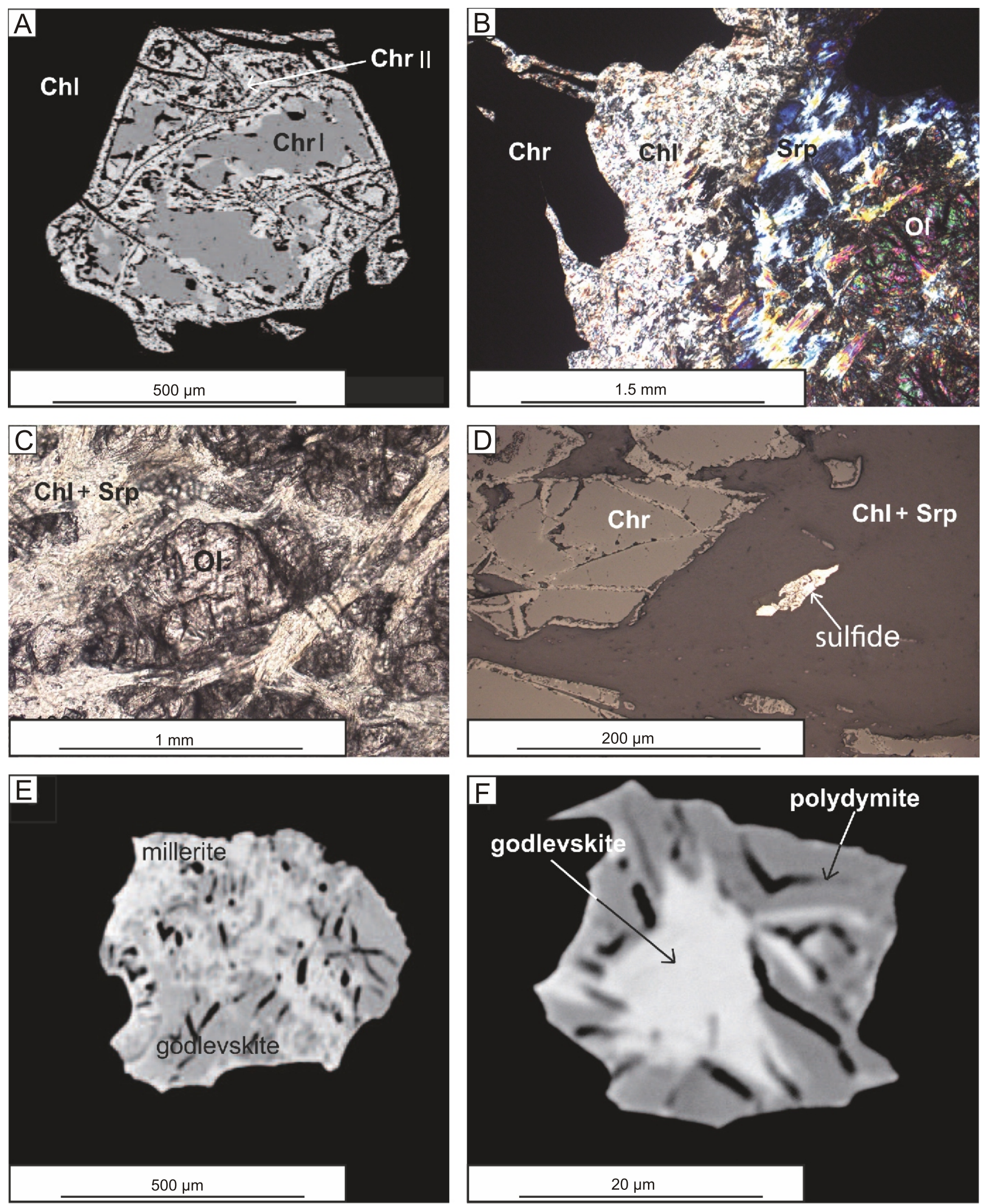

Fig. 4. Textures of the GJSM and BBM chromitites

A - single, heterogeneous chromite grain from the BBM (sample S25), BSE image; B - olivine-serpentine-chlorite groundmass filling the interstices between chromite grains from the BBM (sample S35), optical view, transmitted light, crossed polarisers; C - olivine grains within massive ore, optical view, transmitted plane polarised light; D - sulphide grain within chlorite groundmass from the GJSM (sample S48), BSE image; $\mathbf{E}$ - single, heterogeneous sulphide grain, BSE image from the GJSM (sample S38); F - zoned sulphide grain from the BBM (sample S25), BSE image 
Massive ore contains up to $90 \%$ chromian spinel, Al-rich magnesian chlorite occurs in the interstices. Laminated ore consists of chromite and chlorite-serpentine lamellae and contains up to 50 vol. $\%$ of chromian spinel. The nodular ore consists of rounded aggregates (up to $5 \mathrm{~cm}$ in size) of chromite grains, which are up to $3 \mathrm{~cm}$ across, locally embedded in the chlorite groundmass. The chromian spinel content varies from 30 to 90 vol. \% in this kind of ore. The massive and nodular ores contain xenomorphic sulphide grains occurring (1) in the chlorite groundmass and/or (2) at the margins of chromite grains. Their size varies from 50 to $400 \mu \mathrm{m}$. Sulphide grains are commonly strongly dismembered, heterogeneous and often zoned (Fig. 4E, F). Disseminated Cr-ore contains up to 15 vol. $\%$ of chromite which occurs as small, up to $0.5 \mathrm{~mm}$ across, rounded grains embedded in the serpentinitic groundmass. Small (up to $3 \mathrm{~cm}$ thick) chromite veinlets occur within serpentinite; their shapes are irregular and amoeboidal (Fig. 3F). The serpentinite host rock, in which they occur, shows no fabric. It contains singular patchy olivine grains. The hetero- and mesocumulate textures, and skeletal and vermiform grains have been described by Delura (2012a) and interpreted to be of magmatic origin.

The major element bulk-rock composition of chromitites varies depending on the chromian spinel content (Appendix 2). The content of $\mathrm{SiO}_{2}$ and $\mathrm{MgO}$ is negatively correlated with the amount of chromite in the ore. The trace elements bulk-rock composition of chromitites (Appendix 3) reveals enrichment of $\mathrm{Ba}, \mathrm{Ga}, \mathrm{V}$, slight enrichment of $\mathrm{Sr}$ and $\mathrm{Sc}$, and depletion of $\mathrm{Co}$, $\mathrm{Rb}, \mathrm{Mo}, \mathrm{Cu}, \mathrm{Pb}, \mathrm{Zn}, \mathrm{Ni}, \mathrm{As}$ and $\mathrm{Sb}$ relative to chondrite. The chromitites are depleted in PGE relative to chondrite (Fig. 5 and Appendix 4). The characteristic feature of the PGE composition is the very low amount of these elements $(42-79 \mathrm{ppb}$ of total PGEs).

The chromite grains are irregularly fractured and consist of chromite I and chromite II (Fig. 4A, B). Chromite I occurs mostly in the central part of the grains (cores) and is surrounded by chromite II. The grain margins and fracture zones consist of chromite II. Usually, chromite I predominates in the massive ore, whereas chromite II is common in the nodular or disseminated ore. We found no silicate inclusions within chromite grains, but Delura (2012a) described rare euhedral clinopyroxene (diopside) inclusions. Chromite I has Mg\# between 0.61 and 0.70 , and $\mathrm{Cr} \#=0.50-0.52$. Chromite $\mathrm{II}$ has $\mathrm{Mg} \#$ (0.57-0.69) and $\mathrm{Cr} \#(0.39-0.63)$. Chromite I is not only richer in Al relative to chromite II (Fig. 6), but also shows more consistent compositions in the $\mathrm{Cr} \#$ vs. $\mathrm{TiO}_{2}$ and $\mathrm{Mg} \#$ vs. $\mathrm{Cr} \#$ diagrams (Appendix 5, Figs. 7 and 8).

Chlorite (Appendix 6) is almost purely magnesian and contains variable amounts of $\mathrm{Al}_{2} \mathrm{O}_{3}$ (14.0 to 23.0 wt. $\% \mathrm{Al}_{2} \mathrm{O}_{3}$ ). Marginal parts of chlorite plates, contacting with chromite, contain more Al. Olivine (Appendix 7), occurring in the host serpentinite cut by chromite veinlets, is patchy with the forsterite content varying from 93 to $96 \mathrm{~mol} \%$. Higher-magnesian parts contain $0.45-0.47 \mathrm{wt} \% \mathrm{NiO}$ and up to $0.10 \mathrm{wt} \% \mathrm{MnO}$, whereas lower-magnesian ones - up to $0.52 \mathrm{wt} . \% \mathrm{NiO}$ and $0.12 \mathrm{wt} . \%$ MnO (Fig. 9).

Millerite, godlevskite, polydymite and violarite occur in GJM chromitites (Appendix 8). Millerite has the atomic metal/sulphur ratio between $0.89-1.01$ and contains $0.01-2.90 \mathrm{~mol} \% \mathrm{Fe}$. Small amounts Cu and Co were detected (up to $0.31 \mathrm{~mol} \%$ and up to $0.43 \mathrm{~mol} \%$, respectively). Godlevskite (metal/sulphur atomic ratio $=1.06-1.16$ ) contains up to $1.04 \mathrm{~mol} \%$ Co. Polydymite (metal/sulphur ratio $=0.75-0.80$ ) contains up to $4.00 \mathrm{~mol} \% \mathrm{Fe}$ and $1.00 \mathrm{~mol} \% \mathrm{Co}$. Violarite (metal/sulphur ratio $=0.82$ ) contains $12.40 \mathrm{~mol} \% \mathrm{Fe}$ and $0.70 \mathrm{~mol} \% \mathrm{Co}$. Godlevskite is often replaced by polydymite (godlevskite forms

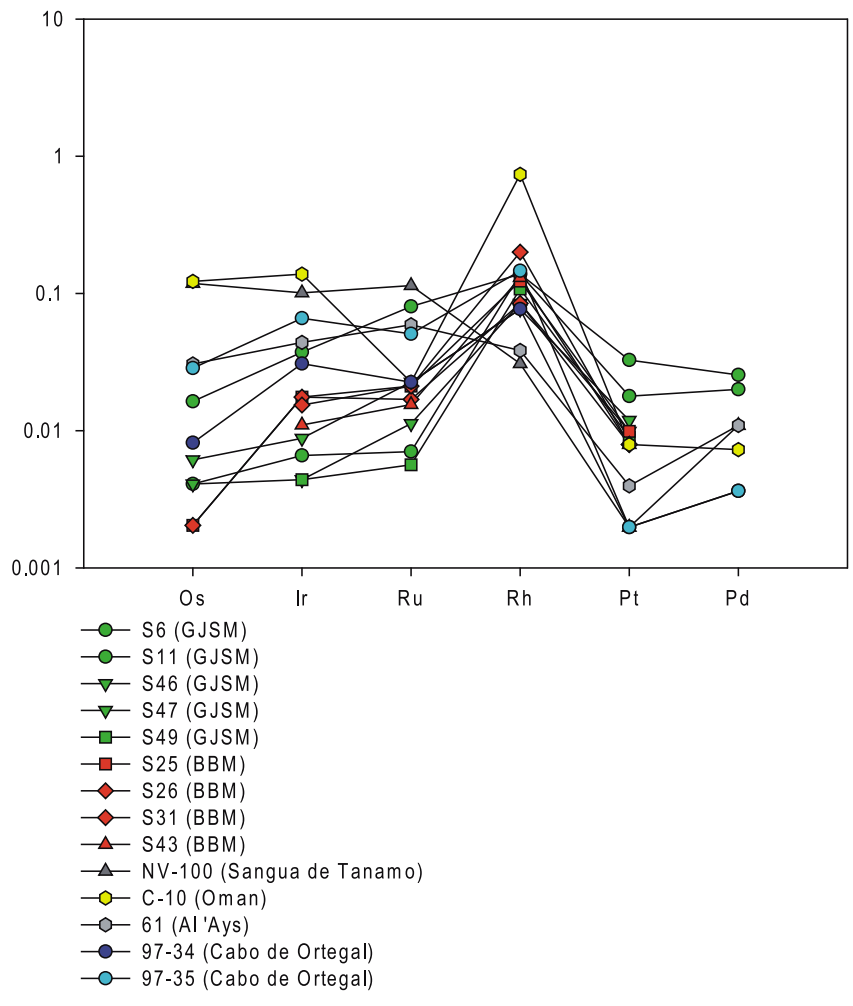

Fig. 5. Chondrite-normalized platinum group element (PGE) patterns of chromitites from the GJSM and BBM chromitites (whole rock analyses)

Patterns for chromitites from Wadi Rajm, Oman (Ahmed and Arai, 2002), Al Ays, Saudi Arabia (Prichard et al., 2008), Cabo de Ortegal (Moreno et al., 2001) and Sangua de Tanamo, Cuba (González-Jiménez et al., 2011), are shown for comparison

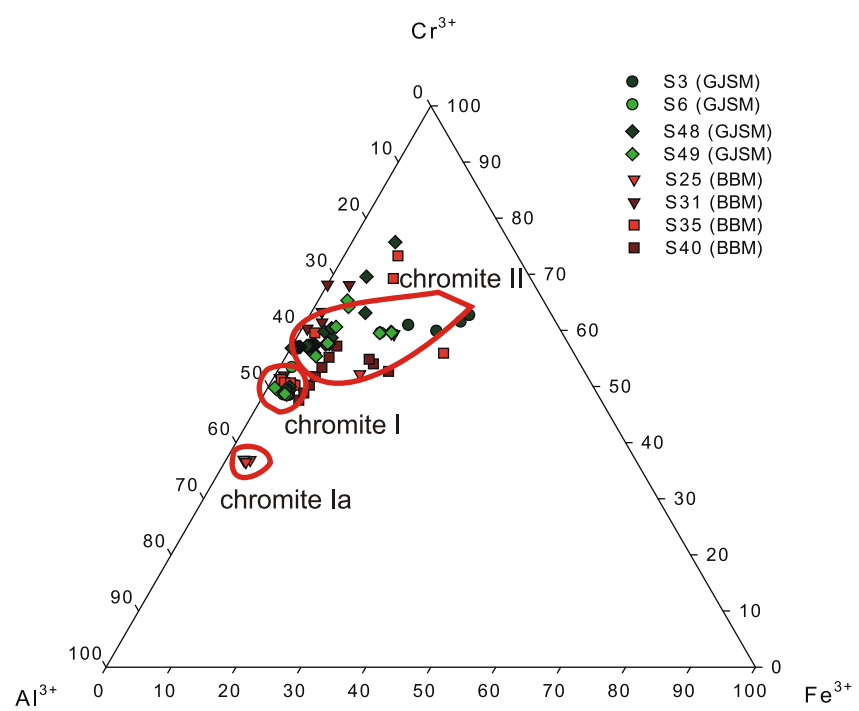

Fig. 6. Composition of chromites from the GJSM and BBM in the $\mathrm{Al}^{3+}-\mathrm{Cr}^{3+}-\mathrm{Fe}^{3+}$ diagram 


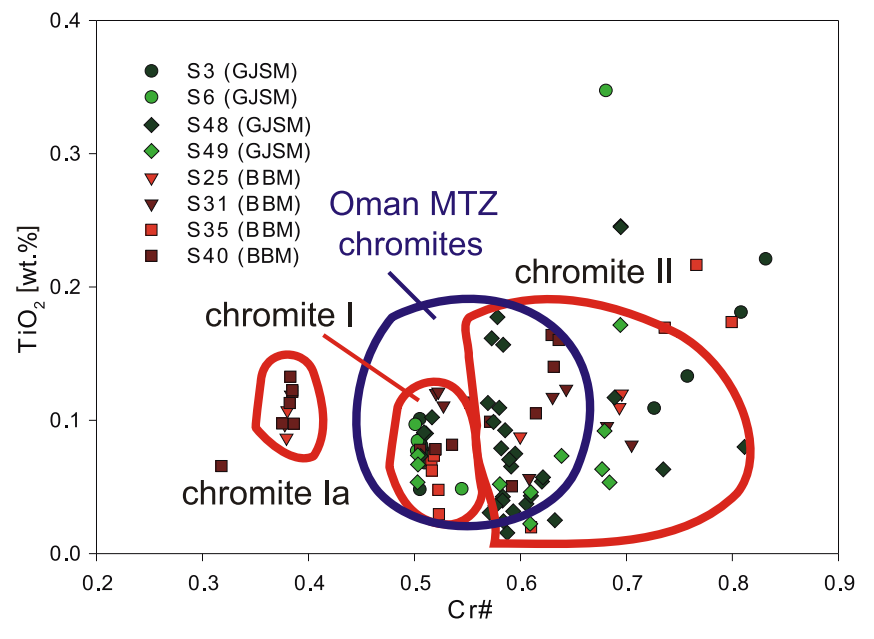

Fig. 7. The $\mathrm{TiO}_{2}$ vs. Cr\# diagram of the GJSM and BBM chromites

Blue field of the MTZ chromites from Wadi Rajm, Oman (Ahmed and Arai, 2002) shown for comparison

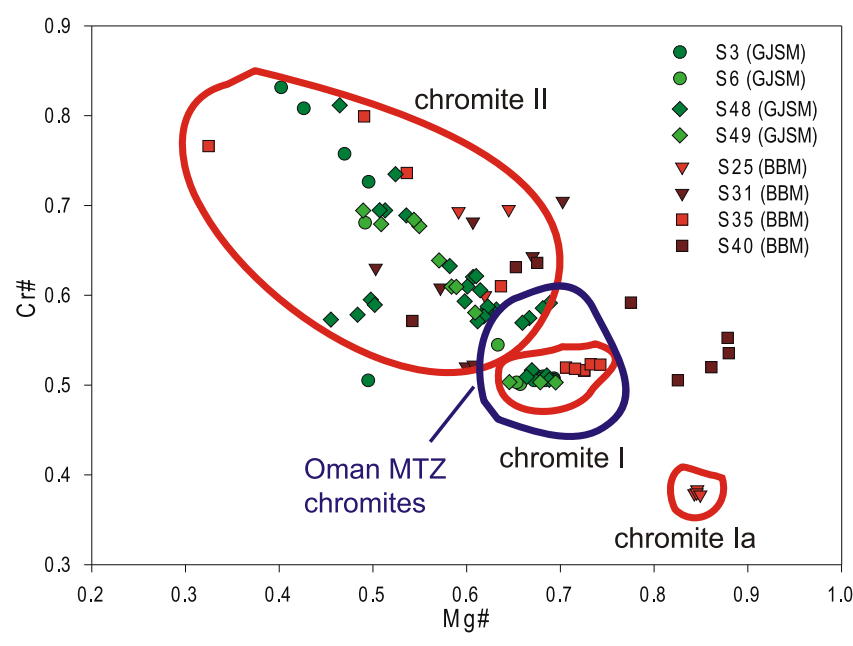

Fig. 8. The Cr\# vs. Mg\# diagram of the GJSM and BBM chromites. Blue field of the MTZ chromites from Wadi Rajm, Oman (Ahmed and Arai, 2002), shown for comparison

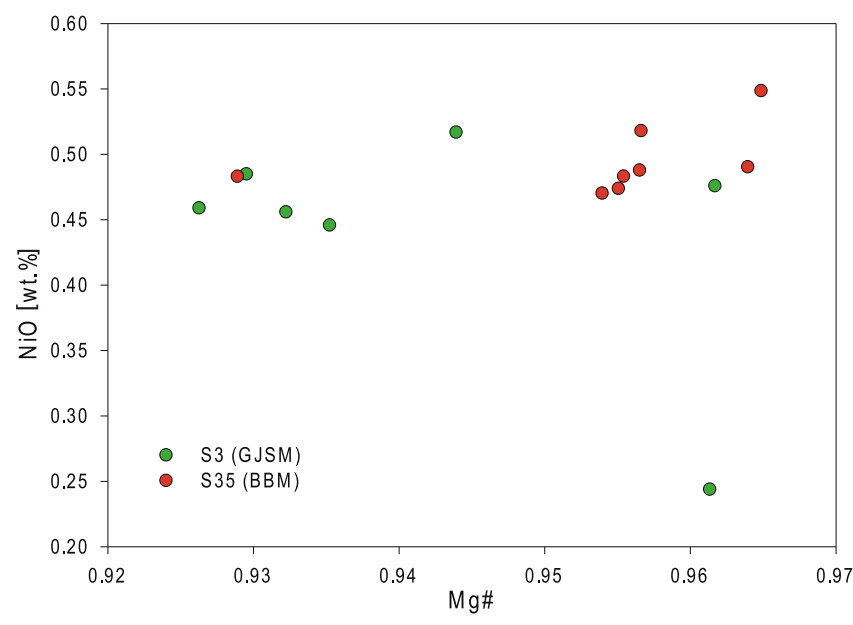

Fig. 9. The NiO (wt\%) vs. Mg\# diagram of the GJSM and BBM olivine associated with serpentinites (green points) or massive ore (red points) cores of grains whereas polydymite occurs as rims), however, numerous sulphide grains are composed of both millerite and polydymite, which show no consistent space relationships.

\section{THE BRASZOWICE-BRZEŹNICA MASSIF}

No data regarding the occurrences of chromitite bodies in the Braszowice serpentinites have been published, except for the information of Kossmann (1890a) about the occurrence of $1-1.5 \mathrm{~m}$ thick chromitite veins in the Grochowiec Hill (50 $33^{\prime} 43^{\prime \prime}$ $\left.\mathrm{N}, 16^{\circ} 45^{\prime} 25^{\prime \prime} \mathrm{E}\right)$. The chromitite bodies were surrounded by alteration zones (salbands) - similar to chromitites from the GJSM (Kossmann, 1890b). The chromitites from the BBM occur within serpentinites of dunitic/harzburgitic composition (Gunia, 1992), which contain abundant relics of olivine and clinopyroxene.

Four types of chromian ore can be distinguished in the BBM (for details see Delura, 2012a): (1) massive, (2) brecciated, (3) nodular and (4) disseminated chromitite. Massive ore $(>90 \%$ chromite) contains also chlorite and highly serpentinised olivine occurring in the interstices. The nodular ore consists of rounded chromite grains up to $3 \mathrm{~cm}$ in size, locally embedded in the chlorite groundmass. Magnesite grains (up to $0.5 \mathrm{~cm}$ ) occur locally within chlorite plates. Brecciated ore (Fig. 3C, E) is probably developed from the pre-existing nodular one. The chromian spinel content is between 30 and 90 vol.\% in the nodular and brecciated ores. Dismembered and heterogeneous, xenomorphic sulphide grains (50 to $800 \mu \mathrm{m}$ ) occur the within massive, nodular and brecciated ores. We found no silicate inclusions within chromite grains. Delura (2012a) described rare high-magnesian $\left(\mathrm{Fo}_{>0.96}\right)$ and $\mathrm{Ni}$-rich $(>1 \mathrm{wt} . \%)$ olivine inclusions within chromite. The heteroadcumulate and mesocumulate textures and skeletal grains were also described by Delura (2012a).

The major and trace element bulk-rock composition of the BBM chromitites is similar to that from the GJSM (Appendices 2 and 3). $\mathrm{The}^{\mathrm{SiO}}{ }_{2}$ and $\mathrm{MgO}$ content is negatively correlated with the amount of chromian spinel in the ore. The BBM chromitites are strongly depleted in PGE relative to chondrite (Fig. 5 and Appendix 4); the PGE content is very low (65-166 ppb of total PGE).

The textures of chromite grains are similar to those occurring in the GJSM chromitites. Thus, chromite I forms the central parts of grains, whereas chromite II is located on the margins and in fissures, and replaces chromite I (Fig. 4A). Chromite I has $\mathrm{Mg} \#$ between 0.60 and $0.70, \mathrm{CH} 0.51-0.52$, $\mathrm{NiO}$ and $\mathrm{MnO}$ $\sim 0.10 \mathrm{wt} \%$ and $\mathrm{TiO}_{2}=0.10-0.14 \mathrm{wt} \%$. Highly aluminous chromite la (Mg\# 0.80, $\mathrm{Cr} \# 0.38, \mathrm{NiO}$ and $\mathrm{MnO} \sim 0.10$ wt\% and $\mathrm{TiO}_{2}$ $=0.02-0.10 \mathrm{wt} \%$ ) occurs in some grains in a number of samples (e.g., sample S25), whereas most of grains consist of chromite I. Chromite II has Mg\# 0.57-0.69, Cr\# 0.39-0.63, NiO and $\mathrm{MnO} \sim 0.25 \mathrm{wt} \%$ and $\mathrm{TiO}_{2}=0.00-0.1 \mathrm{wt} \%$. Despite different chemical compositions between chromite I and la, the coexisting silicate phases have identical composition. Olivine (Appendix 7) from the massive chromite ore $\left(\mathrm{Fo}_{0.95-0.96}\right)$ contains $0.47-0.55 \mathrm{wt} \% \mathrm{NiO}$ and $0.07-0.10 \mathrm{wt} \% \mathrm{MnO}$. Chlorite (Appendix 6) contains little iron and variable amounts of $\mathrm{Al}_{2} \mathrm{O}_{3}$ (14.0 to $23.0 \mathrm{wt} . \% \mathrm{Al}_{2} \mathrm{O}_{3}$ ) depending on the mode of occurrence (more aluminous chlorite occurs near chromite grains).

Millerite, godlevskite, polydymite and carrolite occur in the BBM chromitites occassionaly (Appendix 8). Millerite has the atomic metal/sulphur ratio between 0.76 and 1.0, and contains 0.4-1.3 mol\% Fe. Godlevskite (metal/sulphur atomic ratio = $1.05-1.13$ ) contains up to $0.29 \mathrm{~mol} \% \mathrm{Cu}$ and up to $1.04 \mathrm{~mol} \%$ Co. Polydymite (metal/sulphur ratio $=0.75-0.80$ ) contains up to $4.0 \mathrm{~mol} \% \mathrm{Fe}$ and $1.0 \mathrm{~mol} \% \mathrm{Co}$. Carrolite (metal/sulphur atomic ratio $=0.81-0.85)$ contains up to $1.61 \mathrm{~mol} \% \mathrm{Co}$. 


\section{DISCUSSION}

Chromitites from harzburgites of the GJSM and BBM have similar modes of occurrence, texture, and mineral and chemical composition. They consist of high-Al chromite I and high- $\mathrm{Cr}$ chromite II. Their textural relationships show that chromite I is a primary phase which has been replaced by chromite II. The mode of occurrence of chromitites (pocket- or vein-shaped bodies) suggests that they are of podiform type (Delura, 2012a, b). Nodular texture of the GJSM and BBM chromitites and their podiform nature are the record of igneous crystallisation. The similarity of GJSM and BBM chromitites suggests that they likely crystallised from the same kind of parent melt under similar conditions.

The GJSM chromitites occur within first several hundred metres beneath the Palaeo-Moho (Fig. 10). Since those from the BBM are similar and also occur within the serpentinite host rock, we speculate that their primary position in the ophiolitic section was analogous. The described chromitites occur within the serpentinised harzburgites, thus originated due to chromite precipitation from melt migrating in "dunite channels" in the harzburgitic part of the sub-Moho ophiolite section.

Chromite I has $\mathrm{Cr} \#$ close to 0.50 , with some grains of $\mathrm{Cr} \#$ close to 0.40 (Fig. 2). Thus, they are of high-Al type $(\mathrm{Cr} \#<0.6$, González-Jiménez et al., 2014). The host chromitites are depleted in PGE. The GJSM chromitites are richer in the Pt-group PGE (PPGE) relative to the Ir-group (IPGE) ones (except in one sample out of five samples analysed, cf. Appendix 4). Those from the BBM show non-systematic relationships between the contents of IPGE and PPGE (Appendix 4). Thus, the PGE do not fit the classification of González-Jiménez et al. (2014) who show that the PGE-poor chromitites are enriched in the IPGE relative to PPGE.

PGE-poor chromites crystallise from PGE-poor melt (or platinum group minerals crystallise elsewhere). PGE-poor melts originate (1) when the melting degree is very low, insufficient to extract the PGE from the mantle rocks (Prichard and Brough, 2009), and (2) when the mantle was previously depleted in PGE (Page et al., 1982). Typically, PGE-poor chromitites are considered to have formed in the MOR or suprasubduction zone settings (Prichard et al., 1996). The PGE pattern of the GJSM and BBM chromitites is irregular, mostly flat with only a weak positive Rh anomaly (Fig. 5) which suggests that no significant fractionation of PGE-bearing minerals affected the magma from which chromitite crystallised. The Pd content in the studied chromitites is mostly below the detection limit, which could be explained by high mobility of this element during the alteration processes (Ahmed and Arai, 2002; Prichard and Brough, 2009).

The low PGE content in the studied chromitites and the Cr\# of chromite close to 0.50 correspond to chromitites from the Oman Ophiolite Moho Transition Zone (MTZ) and their chromite (Ahmed and Arai, 2002; Page et al., 1982). In Oman, the high-Al chromitites contain 33-92 ppb total PGEs (Ahmed and Arai, 2002), whereas those from Lower Silesia contain 42-79 ppb (GJSM) and 65-166 ppb (BBM).
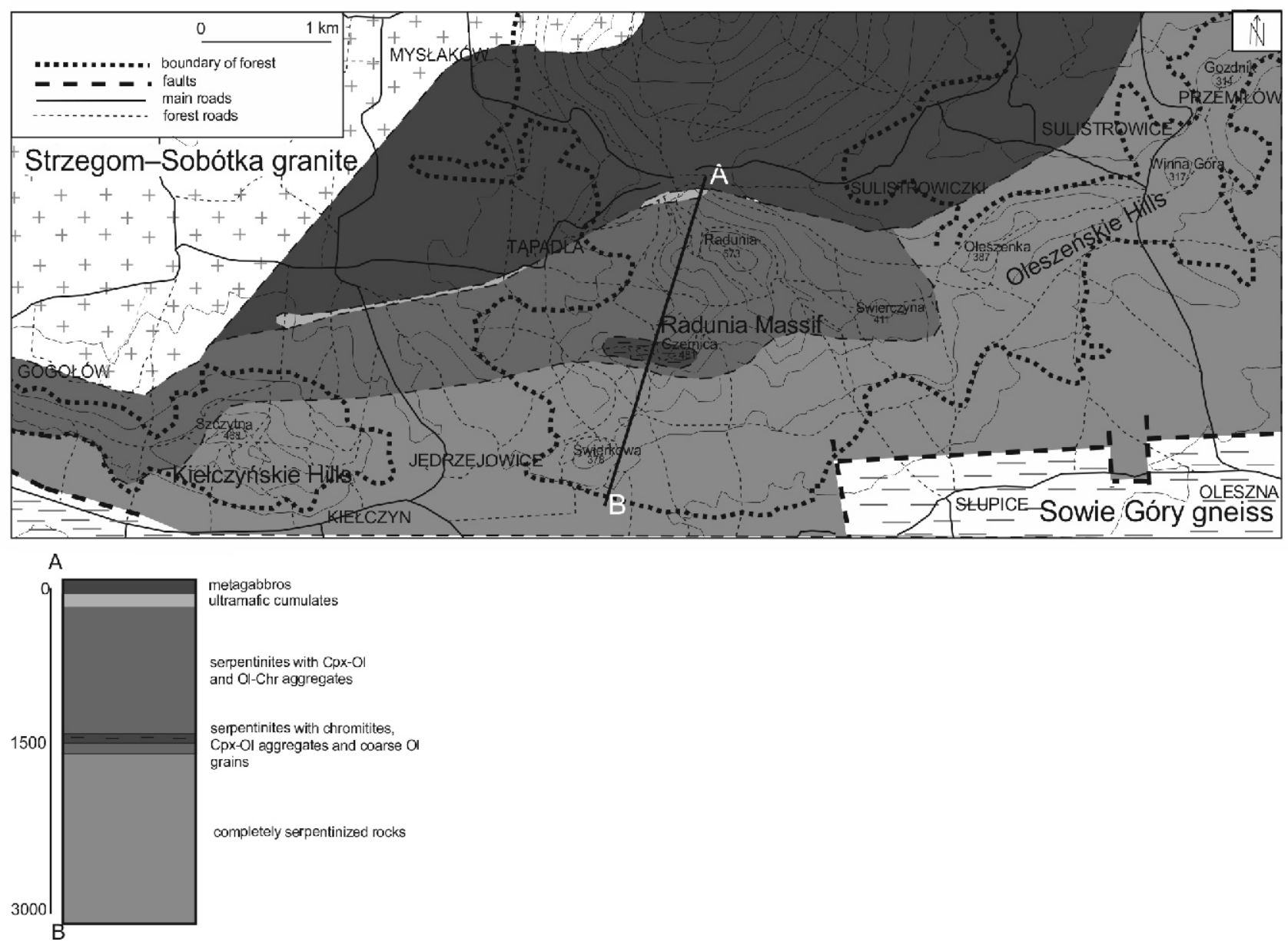

Fig. 10. Geological sketch-map of the southern part of the Ślęża Ophiolite (based on the map by Majerowicz, 2006) and the profile of the sub-Moho serpentinite varieties 
The Moho Transition Zone (MTZ) in ophiolites comprises a dunitic layer with gabbro sills/lenses, concordant wehrlite sills/lenses, and chromite pods, located at the contact between the uppermost mantle harzburgites and the massive layered gabbro of the lower crust (Boudier and Nicolas, 1995; Koga et al., 2001). It is formed by crystal accumulation from mantle-derived basaltic melts occurring at Moho, and by reactive melt percolation leading to the replacement of the uppermost mantle harzburgites (Abily and Ceuleneer, 2013). The GJSM chromitites, located ca.1500 m beneath Palaeo-Moho (Fig. 10), mark the percolation of melts in the uppermost mantle harzburgites immediately below the MTZ (the latter is not described in the Ślęża ophiolite because of very poor exposure).

The melts affecting the MTZ are produced by decompression melting of mantle peridotites, and have a MOR basalt, arc basalt or boninitic composition. Under low pressures, typical of the uppermost mantle, they are undersaturated in silica relative to an orthopyroxene-bearing assemblage, and react with orthopyroxene to produce olivine (e.g., Kelemen et al., 1995). This reaction produces the "dunite envelope" surrounding most of the ophiolitic chromitites. We have not found this envelope, but this is supposedly because (1) our study is based on dumped samples and we had no access to in situ chromitite, and (2) the host serpentinites are heavily serpentinised. Possibly, olivine ( $\left.\mathrm{FO}_{95-96}\right)$ coexisting with chromite in the massive BBM gives a hint of composition of "dunite envelope". Its composition is similar to that of olivines from Oman (Ahmed and Arai, 2002).

Cr solubility in basaltic melt is low (of the order of a few hundred ppm; Roeder and Reynolds, 1991), and oversaturation in $\mathrm{Cr}$ is reached readily, triggering the precipitation of chromitites (Ahmed and Arai, 2002). The silicate phase inclusions (crystallised from the melt) occur typically in this type of chromite (Borisova et al., 2012). Sparse silicate inclusions occurring in the GJSM and BBM chromites were reported by Delura (2012a). The silicate inclusions are, however, not common, which may be due to metamorphic overprint of chromitites.

Chemical composition of chromite occurring in mantle peridotites and ophiolitic chromitites is affected by various geological factors (melt composition, oxygen and water fugacity, pressure and temperature), which are (crudely) governed by tectonic setting (Ghosh et al., 2013, and references therein). The low $\mathrm{TiO}_{2}$ content and aluminous nature of the GJSM and BBM chromites are typical for MORB or arc basalt (Arai et al., 2011; Ghosh et al., 2013), and we suggest that these are the possible tectonic settings of the Lower Silesian chromitites (Fig. 7). However, since many arguments have recently been shown that podiform chromitites do not form in the MOR setting (Rollinson and Adentunji, 2013 and references therein), we argue that the Lower Silesian chromitites originated in the arc setting, and thus fall in the supra-subduction class of ophiolites as defined by Dilek and Furnes (2011).

To obtain more indications about the tectonic setting of the discussed chromitites, we plot their chemical data into the diagram of major, minor and trace elements of chromites normalised to MORB chromite. Because of lack of complete in situ data for chromite, we used analyses of bulk chromitites containing $>90$ vol. $\%$ of chromite as well as one nodular sample containing less chromite. We assume that analyses of chromite-rich bulk rock offer a reasonable approximation of chromite chemical composition. The resulting flat pattern (Fig. 11) fits very well the flat patterns of chromites coming from back arc chromitites (Gonzales-Jimenez et al., 2014: fig. 9), except for the pronounced negative $\mathrm{Zn}$ anomaly in rocks from the GJSM.

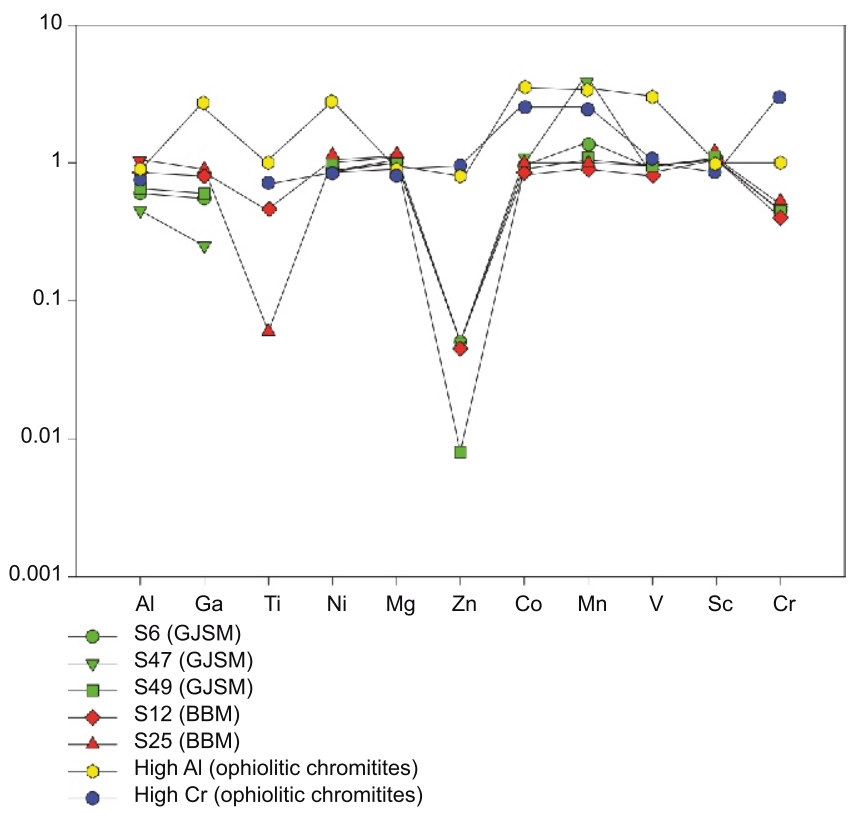

Fig. 11. The patterns of major, minor and trace elements in bulk-rock chromitites, normalised to the composition of MORB chromite (Pagé and Barnes 2009), compared to the patterns of chromite from back-arc chromitites (see González-Jiménez et al., 2014)

All represents normalized $\mathrm{Al}_{2} \mathrm{O}_{3}, \mathrm{Mg}-\mathrm{MgO}$ and $\mathrm{Cr}-\mathrm{Cr}_{2} \mathrm{O}_{3}$

This also suggests the supra-subduction origin of the Lower Silesian ophiolites.

Chromitites from the BBM and GJSM are similar to high-Al chromitites occurring in peridotites of Cabo Ortegal, NW Spain. This Variscan ophiolitic massif is a fragment of the Variscan ocean floor analogous to the GJSM and BBM, and all belong to the Devonian Variscan suture (Arenas, 1991).The high-Al and high- $\mathrm{Cr}$ chromites occur in chromitites from harzburgite, dunite pods and dunite in Cabo Ortegal. The high-Al chromites from harzburgites and dunite pods within harzburgites have $\mathrm{Cr} \#=$ 0.40-0.53, contain 0.21-0.44 wt. $\% \mathrm{TiO}_{2}$, and are PGE-depleted with the total PGE content up to $132 \mathrm{ppb}$ (Moreno et al., 2001). Moreno et al. (2001) interpret that the Cabo Ortegal chromites originate in the back-arc setting.

The secondary alteration of the chromitites has been described in detail by Delura (2012a), thus the reader is referred to that study. Here we comment only on sulphides which have not been discussed in the cited paper of Delura (2012a). Chromite II occurs at the edges and in the fractures of chromite I and replaces it. The chemical composition of chromite II is consistent with the trend typical for metamorphosed chromites that are depleted in $\mathrm{Al}$ and $\mathrm{Mg}$ and enriched in $\mathrm{Cr}$ and $\mathrm{Fe}^{2+}$ (González-Jiménez et al., 2009). Such alteration occurs in the conditions corresponding to those of greenschist metamorphic facies and is related to chlorite precipitation as the product of the reaction between chromite and $\mathrm{Mg}$ - and $\mathrm{SiO}_{2}$-rich fluids (Kimball, 1990), which commonly occur during low-T serpentinisation at $200-300^{\circ} \mathrm{C}$ (Bach et al., 2006). The sulphides occur in the chlorite groundmass or at the margins of chromite grains, which suggests their secondary origin. Sulphide grains are heterogeneous and record evolving crystallisation conditions (e.g., polydymite rims on godlevskite). 


\section{CONCLUSIONS}

Chromitites occurring in serpentinised harzburgites of the Gogołów-Jordanów and Braszowice-Brzeźnica massifs in Lower Silesia (SW Poland) are of podiform type (Delura, 2012b). They preserve the magmatic features, indicating their origin due to crystallisation from basaltic melt which migrated through harzburgites underlying the MTZ. Both chromitites and host serpentinites are overprinted by low-grade (greenschist-facies) metamorphism. The intense serpentinisation of the sub-MTZ peridotites suggests abundance of water during metamorphic overprint, which supposedly occurred in the ocean-floor hydrothermal system. Chromite occurring in the chromitites, despite its magmatic origin, contains very rare silicate inclusions. This is supposedly due to metamorphic recrystallisation by dissolution-reprecipitation, which could have "cleaned" the primary grains from silicate phases.

Pin et al. (1988) suggested that the Ślęża Ophiolite originated rather in the normal MOR setting, although they did not preclude the subduction-related setting. Our study strongly sug- gests that chromitites in both the Ślęża Ophiolite and the Braszowice-Brzeźnica Massif are of arc (i. e. supra-subduction) origin. This interpretation is based on the chemical composition of chromites as well as on much broader knowledge on the origin of ophiolitic complexes which accumulated since the time of study of Pin et al. (1988). The study of host serpentinites should be a next step in assessing the tectonic setting of Lower Silesian ophiolites.

Acknowledgements. We thank two anonymous reviewers and $\mathrm{J}$. Berger for their comments which allowed us to improve this paper. We are also grateful to A. Borisova, G. Ceuleneer and M. Benoit (University Paul Sabatier III, Toulouse) for their inspiring discussions. Thanks go to K. Dymna, P. Matz (University of Wrockaw) and F. Kiraly (University of Vienna) for their technical and analytical assistance. This paper was prepared thanks to the project of National Science Centre of Poland "Evolution of serpentinitic members of the Lower Silesia ophiolites" (DEC-2012/07/N/ST10/03934).

\section{REFERENCES}

Abily, B., Ceuleneer, G., 2013. The dunitic mantle-crust transition zone in the Oman ophiolite: residue of melt-rock interaction cumulates from high-MgO melts or both? Geology, 41: 67-70.

Ahmed, A.H., Arai, S., 2002. Unexpectedly high-PGE chromitite from the deeper mantle section of the northern Oman ophiolite and its tectonic implications. Contributions to Mineralogy and Petrology, 143: 263-278.

Aleksandrowski, P., Mazur, S., 2002. Collage tectonics in the northeasternmost part of the Variscan Belt: the Sudetes, Bohemian Massif. Geological Society Special Publications, 201: 237-277.

Arai, S., Okamura, H., Kadoshima, K., Tanaka, Ch., Suzuki, K. Ishimaru, S., 2011. Chemical characteristics of chromian spinel in plutonic rocks: Implications for deep magma processes and discrimination of tectonic setting. Island Arc 20: 125-137.

Arenas, R., 1991. Opposite P, T, t paths of Hercynian metamorphism between the upper units of the Cabo Ortegal Complex and their substratum (northwest of the Iberian Massif). Tectonophysics, 191: 347-364.

Bach, W., Paulick, H., Garrido, C.J., Ildefonse, B., Meurer, W., Humphris, S.E., 2006. Unravelling the sequence of serpentinization reactions: petrography, mineral chemistry, and petrophysics of serpentinites from MAR 15şN (ODP Leg 209 , Site 1274). Geophysical Research Letters, 25: 1467-1470.

Birecki, T., 1962. Occurrence of chromites at Tąpadła (in Polish with English summary). Przegląd Geologiczny, 10: 144-150.

Borisova, A.Y., Ceuleneer, G., Kamenetsky, V.S., Arai, S., Béjina, F., Abily, B., Bindeman, I.N., Polvé, M., de Parseval, P., Aigouy, T., Pokrowski, G.S., 2012. A new view on the petrogenesis of the Oman ophiolite chromitites from microanalyses of chromite-hosted inclusions. Journal of Petrology, 53: 2411-2440.

Boudier, F., Nicolas, A., 1995. Nature of the Moho Transition Zone in the Oman Ophiolite. Journal of Petrology, 36: 777-796.

Delura, K., 2012a. Chromitites from the Sudetic ophiolite: origin and alteration. Archivum Mineralogiae Monograph, 4: 1-91.

Delura, K., 2012b. Chromitites from the Braszowice-Brzeźnica Massif, Lower Silesia - potential chromium source for industry? Gospodarka Surowcami Mineralnymi, 28: 19-43.
Dilek, Y., Furnes, H., 2011. Ophiolite genesis and global tectonics: Geochemical and tectonic fingerprinting of ancient oceanic lithosphere. GSA Bulletin, 123: 387-411.

Dubińska, E., Gunia, P., 1997. Sudetic ophiolite: current view on its dynamic model. Geological Quarterly, 41 (1): 1-20.

Dubińska, E., Bylina, P., Kozłowski, A., Dőrr, W., Nejbert, K., 2004. U-Pb dating of serpentinization: hydrothermal zircon from a metasomatic rodingite shell (Sudetic ophiolite, SW Poland). Chemical Geology, 203: 183-203.

Dziedzic, K., Dziedzicowa, H., 2000. Genetic relationships between metabasalts and related gabbroic rocks: an example from the Fore-Sudetic Block, SW Poland. Geologia Sudetica, 33: 33-48.

Floyd, P.A., Kryza, R., Crowley, Q.G., Winchester, J.A., Abdel Wahed, M., 2002. Ślęża ophiolite: geochemical features and relationship to Lower Palaeozoic rift magmatism in the Bohemian Massif. Geological Society Special Publications, 201: 197-215.

Ghosh, B., Morishita, T., Bhatta, K. 2013. Significance of chromian spinels from the mantle sequence of the Andaman Ophiolite, India: Paleogeodynamic implications. Lithos, 164-167: 86-96.

González-Jiménez, J.M., Kerestedjian, T., Profenza, J.A., Gervilla, F., 2009. Metamorphism on chromite ores from the Dobromirtsi Ultramafic Massif, Rhodope Mountains (SE Bulgaria). Geologica Acta, 7: 413-429.

González-Jiménez, J.M., Proenza, J.A., Gervilla, F., Melgarejo, J.C., Blanco-Moreno, J.A., Ruiz-Sanchez, R., Griffin, W.L., 2011. High- $\mathrm{Cr}$ and high-Al chromitites from the Sagua de Tanamo district, Mayari-Cristal ophiolitic massif (eastern Cuba): Constraints on their origin from mineralogy and geochemistry of chromian spinel and platinum-group elements. Lithos, 125: 101-121.

González-Jiménez, J.M., Griffin, W.L., Proenza, J.A., Gervilla, F., O'Reilly, S., Akbulut, M., Pearson, N.J., Arai, S., 2014. Chromitites in ophiolites: How, where, when, why? Part II. The crystallization of chromitites. Lithos, 158: 140-158.

Gunia, P., 1992. Petrology of the ultrabasic rocks from the Braszowice-Brzeźnica Massif (Fore-Sudetic Block). Geologia Sudetica, 26: 120-170.

Jędrysek, M.O., Hałas, S., 1990. The origin of magnesite deposits from the Polish Foresudetic Block Ophiolites: Preliminary $\delta^{13} \mathrm{C}$ and $\delta^{18} \mathrm{O}$ investigations. Terra Nova, 2: 154-159. 
Kelemen, P.B., Shimizu, N., Salters, V.J.M., 1995. Extraction of the mid-ocean-ridge basalt from the upwelling mantle by focused flow of melt in dunite channels. Nature, 375: 747-753.

Kimball, K.L., 1990. Effects of hydrothermal alteration on the composition of chromian spinels. Contributions to Mineralogy and Petrology, 125: 337-346.

Koga, K., Kelemen, P.B., Shimizu, N., 2001. Petrogenesis of the crust-mantle transition zone and the origin of lower crustal wehrlite in the Oman ophiolite. Geochemistry, Geophysics, Geosystems, 2: 2000G000132.

Kossmann, B., 1890a. Chromerze in Niederschlesien. Tonindustrie Zeitung, 14: 736.

Kossmann, B., 1890b. Neues Chromeisenerzlager in Niederschlesien. Stahl und Eisen, 12: 1085-1086

Kossmat, F., 1927. Gliederung des varistischen Gebirgsbaues. Abhandlungen Sachsischen Geologischen Landesamts, 1: 1-39.

Kryza, R., Pin, C., 2010. The Central-Sudetic ophiolites (SW Poland): Petrogenetic issues, geochronology and palaeotectonic implications. Gondwana Research, 17: 292-305

Majerowicz, A., 1979. Grupa górska Ślęży a współczesne problemy geologiczne ofiolitów. Wybrane zagadnienia stratygrafii, petrografii i tektoniki wschodniego obrzeżenia gnejsów sowiogórskich i metamorfiku kłodzkiego. Materiały konferencji terenowej Nowa Ruda 8-9 IX. Wydawnictwo Uniwersytetu Wrocławskiego.

Majerowicz, A., 2006. Krótki przewodnik terenowy po skałach ofiolitowego zespołu Ślęży oraz ich petrologicznej i geologicznej historii (in Polish). Acta Universitatis Wratislaviensis 2830, Wrocław 2006.

Moreno, T., Gibbons, W., Prichard, H.M., Lunar, R., 2001. Platiniferous chromitite and the tectonic setting of ultramafic rocks in Cabo Ortegal, NW Spain. Journal of the Geological Society, 158: 601-614.

Page, N.J., Pallister, J.S., Brown, M.A., Smewing, J.D., Haffity, J., 1982. Palladium, platinum, rhodium, iridium and ruthenium in chromite-rich rocks from the Samail ophiolite, Oman. Canadian Mineralogist, 20: 537-548.

Pagé, B., Barnes, S.-J. 2009. Using trace elements in in chromites to constrain the origin of podiform chromitites in the Thetford
Mine Ophiolite, Quebec, Canada. Economic Geology, 104: 997-1018.

Pin, C., Majerowicz, A., Wojciechowska, I., 1988. Upper Paleozoic oceanic crust in the Polish Sudetes: $\mathrm{Nd}-\mathrm{Sm}$ isotope and trace elements evidence. Lithos, 21: 195-209.

Prichard, H.M., Lord, R.A., Neary, C.R., 1996. A model to explain the occurrence of Pt- and Pd-rich ophiolite complexes. Journal of the Geological Society, 153: 323-328.

Prichard, H.M., Neary, C.R., Fisher, P.C., O'Hara, M.J., 2008 PGE-rich podiform chromitites in the Al 'Ays Ophiolite Complex, Saudi Arabia: an example of critical mantle melting to extract and concentrate PGE. Economic Geology, 103: 1507-1529.

Prichard, H.M., Brough, C., 2009. Potential of ophiolite complexes to host PGE deposits. In: New Developments in Magmatic Ni-Cu and PGE Deposits (eds. C. Li and E.M. Ripley): 277-290. Geological Publishing House Beijing.

Python, M., Ceuleneer, G., Arai, S., 2008. Chromian spinels in mafic-ultramafic mantle dykes: Evidence for a two-stage melt production during the evolution of the Oman ophiolite. Lithos, 106: 137-154.

Roeder, P.L., Reynolds, I., 1991. Crystallization of chromite and chromium solubility in basaltic melts. Journal of Petrology, 32: 909-934.

Rollison, H., Adentunji, J., 2013. Mantle podiform chromitites do not form beneath mid-ocean ridges: a case study from the Moho transition zone of the Oman ophiolite. Lithos, 177: 314-327.

Spangenberg, K., 1943. Die Chromerzlagerstätte von Tampadel am Zobten. Zeitschrift für praktische Geologie, 51: 25-36.

Streckeisen, A., 1974. Classification and nomenclature of plutonic rocks, recommendations of the IUGS subcomission on the systematics of igneous rocks. Geologische Rundschau, 63: 773-786.

Wojtulek, P., Puziewicz, J., Ntaflos, T., 2013. The origin of the non-serpentinic phases of the Gogołów-Jordanów serpentinite massif (SW Poland). European Geosciences Union, General Assembly 2013, conference abstract. Online access: http://meetingorganizer.copernicus.org/EGU2013/EGU2013-395.pdf 